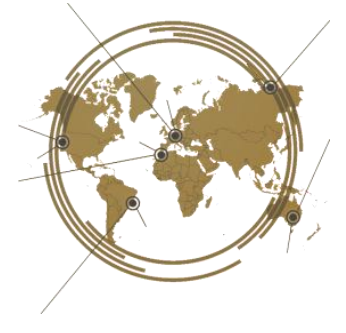

\title{
Autonomous learning features: A case study in an Indonesian ESP classroom
}

\author{
Langgeng Budianto*, ${ }^{1}$ Andrea R. Mason ${ }^{2}$ \\ ${ }^{1}$ English Education Department, UIN Maulana Malik Ibrahim, Indonesia, ${ }^{2} I d a h o$ University, USA
}

This article explores autonomous learning features and effective strategies for meeting the needs of the autonomous learner. A 4-month ethnographic study examined the learning features of three non-English major undergraduates enrolled in an English for Specific Purposes (ESP) course at an Indonesian university. The study also explored the students' and teacher's understanding of how the ESP classroom can benefit the autonomous learner. Data gathered through interviews, focus group discussions, and classroom observation indicates four key autonomous learning features: 1) a willingness to accept responsibility; 2) dedicated planning; 3) implementing effective strategies; and 4) monitoring progress. The findings also indicate that a variety of scaffolded and authentic learning materials combined with a flexible and creative teaching approach enhance autonomous learning. We also address how our results are applicable to most educational situations as autonomous learning is not limited to the language classroom.

Keywords: autonomous learning, ESP, features, self-directed learning

OPEN ACCESS

ISSN 25033492 (online)

${ }^{*}$ Correspondence: Langgeng Budianto langgeng@bsi.uin-malang.ac.id

Received: 26th January 2021 Accepted: 3rd November 2021 Published: 5th December 2021

Citation:

Budianto, L. and Mason, A.R. (2021). Autonomous learning features: $A$ case study in an Indonesian ESP

classroom.

J. Eng. Educ. Society. 7:1. doi:10.21070/jees.v7i1.1213

\section{INTRODUCTION}

Along with global growth, international trade, economic integration, and science and technology, English has established dominance as a global language (Jiajing, 2007; Mauranen, 2016). Consequently, students, academics, and professionals from diverse fields are required to use English, and the demand for English language teaching has grown rapidly (Johns, 2013). Therefore, the university serves a significant role in preparing English language learners to thrive in the global setting. As a response towards the global impact of educational policy in Indonesia, universities are expected to equip and develop student skill, competence, and autonomy. In addition, the university must help students use these attributes to discover, develop, and implement science, technology, and art which are beneficial for humanity (Indonesian government regulation No.19 of 2005, concerning National Education Standard article 26, paragraph 4).

In Indonesia, promoting students' autonomous learning ability is a priority within English language teaching as reflected in university curricula design. While serving the needs of all students, English language instruction is provided to non-English majors through English for Specific Purposes (ESP) courses to provide a framework for improving English proficiency within a student's field of study.

The importance of learner autonomy is well-established, and many countries have set up long-term educational goals to promote students' autonomy (Shang \& Kou, 2015). As Thanasoulas (2002) states, in some cultures, students tend to feel more at ease in the classroom expressing their viewpoints of agreement and disagreement. 
In others, a passive attitude toward the teacher and learning atmosphere is more common. In line with this, learner autonomy has now become a more practical and empirical notion; the concept not only comes in many guises in the classroom, but also links with the theories and pedagogies of lifelong, experiential and technology-enhanced learning that are influencing educational policies and classroom instruction globally (Armitage et al., 2012; Kohonen et al., 2014; Lai, 2017; Lauder, 2008). It is essential to note that autonomy is a process, not a product. One does not become autonomous; one only works towards autonomy (Little, 1991). Further, Benson (2001) notes autonomy can be interpreted as self-access, learner training, individualization, and interdependence.

Key studies focused on identifying autonomous learners' features from varied angles have been conducted, including a study by Chan (2001). The study examined Hong Kong learners' attitudes and perceptions of language learning, teacher and learner roles, learning preferences, and perceptions of learner autonomy. Chan (2001) concluded that the Hong Kong cohort of students displayed several autonomous behaviors, including clear learning objectives, preferred learning styles and positivity about the learning process.

In another key study, Swatevacharkul (2008) explored the readiness for autonomy in a Thai learning context. His project involved 380 students while focusing on willingness, motivation, capacity, and self-confidence for learning autonomously. His results indicated that willingness, motivation, and capacity were considered high, whereas self-confidence was merely moderate.

In the Indonesian context, few studies related to learner autonomy in language learning have been published (Bradford, 2007; Lamb, 2004; Lengkanawati, 2017; Yuliani \& Lengkanawati, 2017). Furthermore, only limited studies have been completed specifically focused on English language learners' features for autonomy in the Indonesian university ESP classroom. Apart from Budianto (2014) study involving ESP students and their experience with using the internet to supplement their in-class learning, there has not been an in-depth investigation to identify the features of autonomous learners.

The following section outlines essential discussion on the differences between learner autonomy and self-directed learning. Afterward, extensive research reviews on both autonomy and self-directed learning and insightful critics of the previous studies are presented as underpinning theory toward the implementation of this study.

Firstly, different experts define the terms learner autonomy and self-directed learning differently. The first definition of learner autonomy refers to learner's ability to take charge of his/her own learning such as determining his/her learning goals, content, progress, and ability to evaluate his/her learning outcomes (Hedge 2000; Little 1995; Lin \& Reinders, 2019). Meanwhile, Thavenius (1999) asserted little bit broader dimension of autonomy including not only ability but also learner's willingness to help her/him to take responsibility of his/her learning.
Meanwhile, the terms self-directed learning is commonly used to describe various types of learners' learning activities and it can also be dichotomized into two different categories, namely learner's learning perspective and learner's personality characteristics perspective (Hartnett, 2015; Ponton \& Carr, 2000). Learner's learning process perspective usually emphasizes on learner's learning activities such as objective setting, planning a learning strategy, teachers, resources selection, and monitoring progress (Oddi, 1987; Ponton \& Carr, 2000).

This notion parallels to self-regulated learning theories where it refers to the both learner' cognitive and behavioral activities in achieving his/her learning goals (Zimmerman, Bonner and Kovach, 1996). Meanwhile, according to psychological perspective, learner's personality characteristics perspective is a process of fulfilling learners' learning needs and learning efforts to achieve learning goals (Ponton \& Carr, 2000). The aforementioned ideas also congruent to Long (1989) who states that learner selfdirected learning can be viewed from both sociological, psychological, and pedagogical perspectives. Long (1989) asserts that learner's sociological dimension addresses learner isolation. Learner's psychological dimension refers to learner's mental state, and learner's pedagogical dimension focuses on learners' learning activities.

Although comprehensive definitions of learner autonomy and self-directed learning are elaborately presented in the previous section but it seems very challenging to technically distinguish between autonomy and self-directed learning. In autonomy learner's learning initiatives is not derived internally from the learner's learning motivation but if is established from the teacher. Conversely, in self-directed learning, learners' learning initiatives is established internally from learner's learning motivation.

Secondly, research on second language (L2) autonomy and self-directed learning are extensive and characterized by several studies on the subject (Borg \& Alshumaimeri, 2019; Hartnett, 2015; Everhard \& Murphy, 2015). Lin \& Reinders (2019), for example, they examined students' and teachers practices of autonomy within EFL classes using the scale of language learner autonomy (SLLA) to assess students practices of autonomy from the perspective of psychological readiness, technical readiness, and behavioral readiness. The participant involved 29 state colleges and universities with 103 students under the blended learning program. The results revealed that students' and teachers were dominant in terms of psychological readiness compared to other dimensions of autonomy such as technical and behavioral readiness for autonomy.

Another research by Borg \& Alshumaimeri (2019) examined teachers' beliefs and practices of leaner autonomy. In the study, they examined four different dimension of autonomy such as the meaning of autonomy, feasibility of autonomy practices, learners' autonomy behavior, and opportunity to develop learners' autonomy from the teachers' perspectives. The participant involved 359 teachers (267 male and 92 female) from more than 50 state and private universities in Saudi Arabia. A mixed designed 
applying a quantitative survey and qualitative thematic analysis were employed to analyze the data. The findings revealed that teachers were considered as the key roles in promoting learner autonomy. The autonomy practices were also shown in the form of encouraging learner's independent works and opportunities to select their own topics.

The next study in the field of self-directed learning conducted by García-Botero, Questier and Zhu (2019), who investigated the impact of out-class learning activities on learner self-directed learning. A number of 112 students in Columbia were participated in the study using a questionnaire and open-ended response to explain the Garrison's (1997) dimensions of self-directed learning. The results found that Duo-lingo application could encourage students' out-of-class learning activities but from the interviews showed that learners were lack of motivation, self-monitoring, and self-learning management.

The aforementioned studies provided a broader horizon of both learner autonomy and self-directed learning from the perspective of autonomy and self-directed learning scale developed by different experts. The findings were fruitful in explaining how autonomy and self-directed learning was perceived by both students and teachers in different context of study. Meanwhile the open-ended questionnaire could qualitatively explain how autonomy and self-directed learning were implemented in the classroom. So far, the results of the previous studies tend to look the existence of autonomy from the product-based side as reflected in the questionnaire. Also, all of the above studies are under the general English classes. So that, the knowledge contributions could not be generalized to different context such as ESP or even EAP classes. However, it is relatively overlooked to investigate the features of autonomy reflected from the perspective of process-based. This study attempts to examine how the features of autonomy are reflected from language learning process under the English for Specific purposes (ESP) class. Furthermore, research has not been conducted to determine how the ESP classroom can be enhanced to meet the needs of the autonomous learner.

Therefore, this study will address two key research questions:

1. What are the key features of the autonomous learner in the Indonesian university ESP class?

2. How can the ESP classroom meet the needs of the autonomous learner?

\section{METHODS}

\section{Design}

The authors decided to employ ethnography, because the ESP learners can be viewed as a subcultural group, processing their aims of learning. Furthermore, ethnography is also mirrored into a research methodology of decoding teachers and learners' learning behaviors through prolonged immersion, observation, and interaction with the member of the target culture group (Li \& Wang, 2018; Wolcott, 2008).
Also, an ethnographical approach was deemed appropriate to examine activities taking place in their natural settings, since the purpose was to interpret the events from the participants' point of view (Creswell, 2008; Maxwell, 1996; Mertens, 2010). Furthermore, relatively few studies have dealt with autonomous learning within the ESP context. This research is part of a one-year ethnographic project that explores the pedagogical transitions of General English (GE) into English for Specific Purpose (ESP) teaching and learning at the Islamic State University of Malang (UIN).

\section{Participants}

The authors did not apply any predesigned criterion to select the research sample since the ethnography is a naturalistic method that requires observation in the natural environment and defined participants and the results cannot be exactly forecasted (O'Reilly, 2008; Li \& Wang, 2018). Consequently, the Science and technology department head introduced the three ESP learners.

The research was conducted at the State Islamic University in Malang, Indonesia - a public university with eight faculties and over 15,000 students. The university curriculum requires students from non-English majors to successfully complete an ESP course. Each ESP course is centered on developing language, skills, and discourse within a specific discipline to support students in their respective fields. Average class size is 25 students.

The study participants were from the Faculty of Science and Technology majoring in Architectural Engineering, Biology, and Chemistry. The three second-year university students, two males ( $\mathrm{L}$ and $\mathrm{K}$ ) and a female (R), were selected based on three factors: 1) their willingness to fully participate in the study, 2) their reputation as motivated students possessing valuable information (Gall et al., 2004), and 3 ) that they represented three different majors at the target university.

\section{Procedure}

During the ethnographic research, the author adopted several different methods to collect the qualitative data through ethnographic interviews unstructured interviews, group interviews, unstructured classroom observations, documentary analysis of the learners, learning materials, notes, and participants observations ( $\mathrm{Li} \&$ Wang, 2018). The authors stayed in the field for four months from September to December to get the fieldwork data through visiting L's, K's and R's classes twice a week, each classroom visit lasted approximately two hours.

The ethnographic interviews were done through casual conversation with the three research participants by revealing participants' interests (Ogden \& Roulon, 2009; Li \& Wang, 2018). Therefore, when the features of learning autonomy from the three ESP students were identified, an explanation was then taken into consideration. These unstructured interviews were also repeatedly and insightfully enquired about learners' experience during their ESP learning. The unstructured interviews ranged from 30 minutes to 2 hours in length, and they were usually 
administered during lunch time after the classroom observations. The interview concept was applied using Magg-Raport's (2000) model to draw learners' insights occurred in particular space and time.

Next, the unstructured classroom observation was conducted to enrich the authors' understanding of the autonomy features and the needs of autonomy of from the ESP class (Robson, 2011; Li \& Wang, 2018), particularly on the learner's autonomy needs, features and learning activities. To maintain the natural setting and avoid obstructive effects, the authors did not let the ESP teachers introduce them formally to the learners during the whole research process.

\section{Data Analysis}

Transcripts from the participants were analyzed using a combined deductive and inductive coding using thematic analysis approach (Fereday \& Muir-Cochrane, 2008). Deductive approach was applied to determine codes to autonomy and needs features. Meanwhile, the inductive approach was employed to explore the detail themes emerge from the study (Rivas, 2012). Similarly, deductive-inductive approaches undertaken by Mintz, Branch, March, \& Lerman (2012), the authors used broad deductive codes to lead the data interpretation based on the autonomy needs and features. To identify major themes, the authors also considered the codes of autonomy feature and learner's needs in the initial stages. As the second step, inductive codes were generated from the data based on the preestablished themes. Subsequently, the above steps were followed by a customary procedure for the thematic analysis revisions of the codes applying iterative and reflexive process by comparing and contrasting to emerge 'valid' themes (Tesch, 1990). For coding reliability, the thematic analysis was performed three times, and the coding of each transcript was compared through researchers' team.

\section{RESULTS AND DISCUSSION}

\section{Research Question (RQ) 1: What are the key features of the autonomous learner in the Indonesian university ESP class?}

The findings derived from the study are divided into two subsections: interview responses and analysis, followed by results from a focus group discussion (FGD) and classroom observation focused on course materials and teaching approach. The following excerpts represented how ESP learners described their roles as autonomous learners. Thematic coding process was applied to analyses the responses to the open-ended questions. From the interviews, four autonomous learning sub-themes were identified: perceiving language learning, establishing learning objectives, implementing language learning strategies, and monitoring the learning process.

\section{Perceived language learning}

First, the three ESP learners explain how they perceived themselves as language learners in the ESP class. The first respondent $\mathrm{L}$, he was a 19 -year-old male student in his fourth semester from the Architectural Engineering department who enjoys reading English language text books in his spare time. The second respondent $\mathrm{K}$, he was an 18year-old male student from the biology department. He demonstrates intermediate-level proficiency in an ESP class. His previous experience in learning English was with a native English speaker for four years in high school. The third respondent, $\mathrm{R}$, she was an 18-year-old female undergraduate student majoring in Chemistry. She was enrolled in three concurrent language courses (Mandarin, German and English).

1. English is fun, even though it was a difficult language to learn I feel that I'm good in ESP class. I am able to manage myself. I have goals for ESP here. I want to develop myself and increase my skills in speaking. I want to speak like a native speaker and with that skill I can go around the world.

2. I think studying English through an intensive course in the university Language Center makes me well motivated to speak with teachers and friends. The classroom learning environment encourages me to speak.

3. Even though I take a science program, when I got difficult words on the text, I usually write those words on my book. I do not open dictionary to see the meaning of the words, but I guess the meaning from the context.

The three respondents perceived themselves utilizing autonomous learning attributes in their English language studies. For example, L demonstrated an attitude of responsibility for his learning by establishing clear incremental goals as a self-directed learner. $\mathrm{K}$ described how he remained motivated within the ESP class, while R expressed her self-directed learning preference by taking initiatives to challenge herself.

\section{Establishing learning objectives}

Second, regarding learners' learning objective in ESP class, the three learners express their opinion below.

1. Well, for me, my English language learning objectives are now and then. My short target is that I am able to speak English in the near future. Another target is to complete my ESP course so that I can get the one-year English certificate for my university regulation. The one-year English certificate will surely be used for the faculty requirement to sit in comprehensive examination in the next three semesters. And it is also prepared me for my job in the future.

2. Ok, I must get a good score in my English class. Having higher TOEFL score and getting the one-year ESP certificate are my serious concerns. If I cannot reach the minimum TOEFL score I will fail and retake the next semester. TOEFL with a higher score will help 
me to compete my job later. Being able to speak English well is my other concern in the near time. I believe when I continue my S2 (master degree) program abroad, good communication is needed. Current technology also requires lots of English abilities on programming it.

3. I think, oral English is my objective to master in the one-year English program under the Language Center. This academic English helps me practice my speaking with friends and teachers. Besides, my objective is joining the English graduation day then I get the oneyear English certificate. Because ESP program campus is equal to Diploma one.

All ESP respondents expressed their remarks differently. The primary learning objective appeared to be earning the required one-year English certificate through successful completion of the ESP course. Beyond meeting basic requirements, the students' secondary objectives were both short and long-term. For instance, short-term objectives included gaining speaking proficiency as shared by L and R, while long-term objectives were based on the need for English language skills to pursue graduate education, qualify for career opportunities, and navigate technology, as described by $\mathrm{L}$ and $\mathrm{K}$.

\section{Implementing language learning strategies}

In terms of the implementation language learning strategy, the three respondents implemented different learning strategies in their ESP as illustrated in the following excerpts.

1. Ehm, let me think. Well, I use suitable reading strategies to enlarge my words. For example, I will look at critically unfamiliar words by trying to find the meaning, synonym and type of words whether adjective, verb, noun, and adverb. I pay special attention that through this way looks more effective. I like to learn on my way.

2. As far as I am concerned, I often listen to western music to develop my speaking performance. With this way I can learn to pronounce and say words properly without the teachers' attendance. Besides, I can also learn a cultural context.

3. An extra related text usually provided by my lecturer to support the related topic, but I usually find another text that I like for my critical thinking. It is interesting for me to read and understand on my own than with a group. Sometimes I like to be in a study group because we have different levels of understanding among the group members. To me individual understanding is not enough. The findings imply that learners can identify and adopt relevant strategies that encourage autonomous learning. Language learning strategies are the learner's goal-directed actions for improving language proficiency or achievement, completing a task, or making learning more efficient, more effective, and easier" (Oxford, 2011b, p. 167). All three respondents implemented independent learning strategies to control certain aspects of their learning within the ESP context. For example, L reported in detail his approach to vocabulary building, $\mathrm{K}$ relied upon music to improve his pronunciation, while Rosa searched for additional texts to augment her learning. In addition, $\mathrm{R}$ also identified that an independent learning approach is not sufficient for her learning and sought group work to enhance her studies.

\section{Monitoring the learning process}

Each ESP learners performed different ways in monitoring his/her learning progress whether it took place in the classroom or out-class learning activities. The following scripts illustrated the way learner monitored his/her learning process and progress.

1. Well, I'm very task oriented, I often ask myself when I should monitor the process of myself-study. For example, I often question myself whether I can do my homework assignments and see the progress is going with them

2. Ok, most frequently, monitoring my language learning, I take notes to whatever topics given by my lecturer. For example, if my English did not reach to the main purposes then self-correction is done. I question myself such as where did I go wrong? How do I fix things?” and of course, I will reward myself.

3. For me, reflecting on self-study is often made. When I speak with friends and teachers, I often recheck whether I used correct words and grammar to my sentences. I am clearly sure that learning to speak English counts a lot of considerations of correctness. That is why I often try to perform a proper way to drill my conversation on the way to pronounce and to use grammar.

All the participants expressed that self-monitoring is critical for improving their respective language skills, although they employed different methods. L systematically monitored his progress through task completion, while $\mathrm{K}$ implemented a holistic approach through self-assessment, resolution, and reward. Meanwhile, $\mathrm{R}$ focused on reflection to help her identify improvement opportunities. Through differing monitoring methods, each participant remained motivated, organized, and focused on their learning goals.

\section{Research Question (RQ) 2: How can the ESP classroom meet the needs of the autonomous learner?}

To expand the understanding of autonomous learning beyond the interviews of study participants, the researchers facilitated a focus group discussion (FGD) and conducted classroom observation. The FGD explored the connection between ESP learning needs, course materials and teaching activities on autonomous learning, while the observation spotlighted teaching approaches. The researchers found that ESP teachers used a mix of general English textbooks as well as supplemental material to link language learning to professional fields of study. Regarding teaching approaches, results indicated specific characteristics that support autonomous learning. 
In the comments below, the participants illustrate the impact of the leaning needs, materials and teaching approach on their autonomous learning skills including planning, motivation, and self-confidence.

1. The handout given to us is interesting since it contains with relevant daily examples. The course offered with different activities sounds interesting for me. When the teacher gives me with samples of dialogues and working with role plays, I am bashful at first, but then I am happy since my classmates were nicely performing the dialogues. I need to schedule the activities first just like doing a homework especially exercises on grammar that attract my interest because I enjoyed doing some exercises without taking up my time a lot.

2. The language function of idiomatic expressions used in the sample conversation are treasured to be applied in my future work. Happily, I am also practicing with my classmates and they welcome to demonstrate words trained in a conversation. For me, everyday language functions are nice to use. Many linked-terminologies to my discipline are being studied where I almost never used them. Right now, in everyday talked with my classmates and roommates, I must use them communicatively. I often engage myself in various ways when class is outside. I'm well-motivated learning outside classroom with internet or $\mathrm{CD}$ recording to listen over and over again

3. The dialogues in the prepared-worksheets are suitable with my major. I like the exercises given in the worksheets. I speak to overseas students with such a model. The activity provided was fascinating to practice English, even if I lack of using English. However, I still tend to practice the language expressions with friends outside because it is in need and useful when I talked with friends in the campus. I also enjoy learning English song from online YouTube

The study participants shared that learning from bookbased materials is useful as the texts are organized and specifically developed for the English language learner. Moreover, the ESP textbook materials provided a framework for independent learning. However, textbooks maybe outdated and not well-aligned with topics that engage learners, nor did the texts support discourse skill building within any specific discipline. Because of the limitations of prescribed general English textbooks, the researchers noted that learning activities were often augmented through role plays, conversations, and dialogues connected with authentic situations.

Through classroom observation, the researchers identified effective teaching approaches that enhanced autonomous learning - providing flexibility and fostering creativity. The teacher created a flexible learning environment by allowing students to choose to either work in groups or on their own. Creativity was fostered through encouraging students to develop problem solving skills, like Zhao's (2009) conclusion that high-level cognitive skills such as problem solving, and critical thinking provide rich experiences of learning autonomously.

In this section, the findings are discussed and interpreted in response to the two research questions. The practical implications of the study outcomes for encouraging autonomous learning beyond the ESP classroom are also presented.

\section{Key features of the autonomous learner in the Indonesian university ESP class}

A willingness to accept responsibility for active learning appears to be the foundational feature of an autonomous learner. Rather than relying only on the instructor and course materials, an autonomous learner demonstrates initiative in learning through robust planning, implementing effective strategies, and systematically monitoring and evaluating progress.

As indicated in the results, autonomous learners begin with planning; plans for lessons, for a course, and for the future. Through autonomous learning, language learners set targets and objectives within the framework of the ESP class, as well as outside of the class. In this study, all respondents are focused on the short-term goal of meeting university requirements by obtaining the one-year English certificate. Beyond the short-term goal, each learner's longterm goals vary depending upon career choices or interest in further education. Through careful planning, the autonomous learners demonstrate a self-directed commitment to achieving their learning goals. These findings reported their similar and different results to some previous studies. The similarity was reported in terms of general autonomous cycles involving planning, implementing, and evaluating students' learning (Borg \& Alshumaimeri, 2019; Budianto, 2014; Hartnett, 2015; Yuliani \& Lengkanawati, 2017). Meanwhile, within a specific ESP content the cycles involved more challenging skills. The ESP learners not only required to learn general English but also to learn specific English (their content knowledge in English) as their major. This is the novelty of the study. Therefore, this study provides specific add to the theory of autonomous learning.

In addition to implementing active planning, the results illustrate how the students identify and adopt effective learning strategies that meet their individual needs and help them reach their targets. This study was also found in Lin \& Reinders's (2019) and Chan's (2001) studies. They reported that learners' learning preferences become crucial factors in promoting students' autonomous learning. Autonomous learning represents an intentional activity in which learning is pursued based upon individual preferences. These preferences provide a motivating framework for pursuing independent learning as a supplement to the ESP class such as seeking additional English texts or listening to Western music as discussed in the findings. Further, through an autonomous learning strategy, students can determine their respective monitoring model without pressure which creates a more relaxed and enjoyable learning experience.

On the other hand, an autonomous learner may embrace their preference for group work as also noted in the findings. 
Community activities allow learners to become involved in personal growth and engagement, by helping classmates, by discovering how to make choices, and by gaining selfconfidence. Both independent and group learning strategies are markers of autonomous learning.

An autonomous learner values monitoring and evaluating their language learning progress. The aim is for students to track their accomplishments, recognize improvement opportunities, and develop an action plan to fill their knowledge gap. In this study, each respondent adopted a different monitoring and evaluation plan. The three subjects $\mathrm{L}, \mathrm{K}$ and $\mathrm{R}$ indicated different processes of autonomy such as monitoring learning progress using a specific task, holistic approach, and regular reflection strategies. Although the methods may vary, the results indicate that all the research participants perform their active learning by actively monitoring their language learning process.

\section{The needs of the autonomous learner in the ESP classroom}

Through teaching via a learner-centered approach, the ESP students in this study were able to perceive positive learning experiences. Because autonomous learning represents an intentional activity in which learning is pursued based upon the individual, a basic premise of teaching autonomy is allowing freedom of learner choice to enhance performance without relying on the teachers' guidance. The inclusion of self-regulation into the learner autonomy framework improves our understanding of how teachers can support their learners' development of autonomy and promote the appropriate conditions necessary for this development (Nakata, 2014).

As previously noted, autonomous learning is often affected by the teacher's approach, as well as class materials as indicated in the findings. In this study, teachers adopted a structured, but flexible, approach to encourage learners in the ESP classroom. Rather than relying on a static textbook, teaching was enriched through supplemental materials. By creating authentic and practical tools for ESP learners, students gained language proficiency via role plays and dialogs applicable to their field of study. Due to the numerous undergraduate majors and flux in related careers, ESP materials require regular review and updating to meet students' needs. Maintaining an effective connection between learning materials and professional discourse requires commitment by the teaching staff. Often, survey tools are implemented to assess students' needs with data collected from subject area experts and students.

Additional resources in the ESP classroom can support the autonomous learner, especially technology-based opportunities. Technology can influence students' motivation to learn while increasing their involvement in and out of the classroom. (Ilter, 2009; Jay, 2006; Kassim \& Zuraina, 2007; Reksten, 2000). Technological tools provide students with flexibility to learn at any time and at any location. Yet, the need for using modern technologies in the ESP instructional environment presents a challenge for the teacher. The ESP teacher needs to provide a relevant framework for students to construct knowledge and become active participants in the learning process. Through facilitating constructivist dialogue in the ESP digital classroom, the teacher can guide students in building autonomous learning skills.

\section{Implications}

Although this study focused on key features of autonomous learning within the ESP context, the results are applicable to most educational situations. Nurturing responsible learners that can design, implement, and monitor their learning through effective strategies results in autonomous learners in other content areas. Beyond building proficiency in the subject manner, the key features can foster desirable characteristics including leadership, diligence, and selfawareness. Autonomous learning also offers the learner the ability to understand how to develop and function more effectively as self-directed individuals.

Other implications involve the teacher's approach. Adopting and promoting a spirit of independent learning provides learners with a supportive framework to develop and practice autonomous learning habits. Within this framework, the teacher can introduce or expand expectations for autonomous learning while utilizing authentic and practical learning tools. Furthermore, by readily adopting and integrating technology-based teaching into the classroom, teachers can create a robust learning environment that is not only resourceful, but also provides variety to meet individual needs.

\section{CONCLUSION}

This ethnographic case study has extended understanding of the autonomous learner by not only highlighting key features noted in previous studies, but by adding insight through indepth analysis. Moreover, the study revealed strategies for meeting needs of an autonomous learner through authentic materials and effective teaching approaches. Although this study was conducted within an ESP context, the results are clearly applicable to other learning contexts.

The study confirms that a willingness to accept responsibility for active learning appears to be the foundational feature of an autonomous learner. In addition, the results provide a roadmap of how an autonomous learner may approach learning via vigorous planning, implementing effective strategies, and systematically monitoring and evaluating progress.

Based on the study's results, we have suggested adopting flexible and creative teaching approaches that foster autonomous learning. By establishing an adaptable framework, a teacher can support students at various stages of autonomous learning. Furthermore, as indicated in the study, a teacher enhances the learning experience by utilizing a variety of materials. In the ESP classroom, a combination of traditional language textbooks and authentic supplementary handbooks provided the essential connection 
to the non-English majors' chosen discipline. The autonomous learners in this study indicated that the benefits of role playing, creating dialogs, and working with technological tools helped them reach their learning goals.

Looking beyond the ESP classroom, the results are transferable to other educational environments. Encouraging students to perceive themselves as an autonomous learner is essential. Then, by fostering self-awareness and self-directed learning, teachers can stimulate responsible learners to plan, implement, and monitor their learning through effective strategies.

\section{ACKNOWLEDGEMENTS}

The authors would like to thank you to Dr. Yudhi Arifani for his fruitful suggestions, comments, and serious edits throughout this manuscript. Finally, we also express our gratitude to anonymous reviewer of this journal for insightful notes and comments.

\section{REFERENCES}

Armitage, A., Evershed, J., Hayes, D., Hudson, A., Kent, J., Lawes, S., Poma, S., \& Renwick, M. (2012). Teaching and training in lifelong learning (4th ed.). Maidenhead: Open University Press

Benson, P. (2001). Teaching and researching autonomy in language learning. London: Longman.

Borg, S., \& Alshumaimeri, Y. (2019). Language learner autonomy in a tertiary context: Teachers' beliefs and practices. Language Teaching Research, 23(1), 9-38.

Bradford, A. (2007). Motivational orientations in underresearched FLL contexts: Findings from Indonesia. RELC, 38(3), 302-323.

Budianto. L. (2014). Students' Autonomous Learning through ICT based Learning in ICP: A case study. LINGUA, 9(2), December 2014. 128-134.

Chan, V. (2001). Readiness for learner autonomy: What do our learners tell us? Teaching in Higher Education, 6(4), 505-518.

Creswell, J. W. (2008). Educational research: Planning, conducting and evaluating quantitative and qualitative research (3rd.ed). Upper Saddle River, NJ: Pearson Education

Everhard, C.J., \& Murphy, L. (Eds.). (2015). Assessment and autonomy in language learning. Basingstoke: Palgrave Macmillan.

Fereday, J.\&Muir-Cochrane, E. (2008). Demonstrating rigor using thematic analysis: A hybrid approach of inductive and deductive coding and theme development. International Journal of Qualitative Methods, 5(1), 80-92.

Gall, M., Borg, W. \& and Gall, J. (2004). Quantitative and qualitative research methods in educational sciences and psychology. Ahmad Reza Nasr et al. (Trans.). Tehran: SAMT
García-Botero, G., Questier, F., \& Zhu, C. (2019). Selfdirected language learning in a mobile-assisted, outof-class context: Do students walk the talk? Computer Assisted Language Learning, 32(1-2), 7197.

Garrison, D. R. (1997). Self-directed learning: Toward a comprehensive model. Adult Education Quarterly, 48(1), 18-33.

Hartnett, M. K. (2015). Influences that undermine learners' perceptions of autonomy, competence and relatedness in an online context. Australasian Journal of Educational Technology, 31(1).

Hedge, T. (2000). Teaching and learning in the language classroom. Oxford: Oxford University Press.

Ilter, B. G. (2009). Effect of technology on motivation in EFL classrooms. Turkish Online Journal of Distance Education-TOJDE, 10(4).

Jay D. A. (2006). Motivating for writing through blogs. A Master thesis submitted to the Graduate College of Bowling Green State University. Available online at http:// etd.ohiolink.edu

Jiajing, G. (2007). Designing an ESP course for Chinese university students of business. The Asian ESP Journal, 3(1), 97-106.

Johns, A. M. (2013). The history of English for specific purposes research. In B. Paltridge \& S. Starfield (Eds.), The handbook of English for Specific Purposes (pp. 5-30). WestSussex: John Wiley\&Sons, Inc.

Kassim, H. \& Zuraina, A. (2007). The use of ICT in the implementation of student-centered learning (SCL). Internet Journal of e-Language Learning \& Teaching, 4(1). pp. 15-31.

Kohonen, V., Jaatinen, R., Kaikkonen, P., \& Lehtovaara, J. (2014). Experiential learning in foreign language education. New York, NY: Routledge

Lamb, M. (2004). 'It depends on the student's themselves': Independent language learning at an Indonesian state school. Language, Culture and Curriculum, 17(3), 229-245

Lai,C. (2017). Autonomous language learning with technology. Beyond the classroom. London \& New York: Bloomsbury Academy

Lauder, A. (2008). The status and function of English in Indonesia: A review of key factors. Makara, Social Humaniora, 12(1), 9-20.

Lengkanawati, N. S. (2017). Learner autonomy in the Indonesian EFL settings. Indonesian Journal of Applied Linguistics, 6(2), 222-231.

Li, Y., \& Wang, L. (2018). An Ethnographic Exploration of Adopting Project-Based Learning in Teaching English for Academic Purposes. Electronic Journal of Foreign Language Teaching, 15(2).

Lin, L., \& Reinders, H. (2019). Students' and teachers' readiness for autonomy: Beliefs and practices in developing autonomy in the Chinese context. Asia Pacific Education Review, 20(1), 69-89.

Little, D. (1991). Learner autonomy. 1: Definitions, issues and problems. Dublin: Authentik 
Little, D. (1995). Learning as dialogue: The dependence of learner autonomy on teacher autonomy. System, 23(2), 175-182.

Long, H. B. (1989). Self-directed learning: Emerging theory and practice. In Long, H.B. and Associates (Eds.) Self-Directed Learning: Emerging Theory and Practice. Norman, OK: Oklahoma Research Center for Continuing Professional and Higher Education of the University of Oklahoma, pp. 1-11.

Mauranen, A. (2016). English as the Academic Lingua Franca. English for Specific Purpose Journal, 3.

Maggs-Rapport, F. (2000). Combining methodological approaches in research: Ethnography and interpretive phenomenology. Journal of Advanced Nursing, 31(1), 219-225.

Maxwell, J. A. (1996). Qualitative research design: An interactive approach. Thousand Oaks, CA: Sage Publications

Mintz, J., Branch, C., March, C., \& Lerman, S. (2012). Key factors mediating the use of a mobile technology tool designed to develop social and life skills in children with Autistic Spectrum Disorders. Computers \& Education, 58(1), 53-62.

Mertens, D. M. (2010). Research and evaluation in education and psychology: Integrating diversity with quantitative, qualitative, and mixed methods. Thousand Oaks, CA: Sage Publications

Nakata, Y. (2014). Self-regulation: Why is it important for promoting learner autonomyin the school context? Studies in Self-Access Learning Journal, 5(4), 342356

Oddi, L. F. (1987). Perspectives on self-directed learning. Adult Education Quarterly, 38. 21- 31.

Ogden, A., \& Roulon, S. (2009). From field projects in anthropology: A student handbook. Illinois: Waveland Press Inc.

O'Reilly, K. (2008). Key concepts in ethnography. London: Sage.

Oxford, R. L. (2011b). Research timeline: Strategies for learning a second or foreign language. Language Teaching, 44(2), 167-180.

Ponton, M. K., \& Carr, P. B. (2000). Understanding and promoting autonomy in self-directed learning. Current research in social psychology, 5(19), 271284.

Reksten, L. E. (2000). Using technology to increase student learning. California: Corwin Press, Inc.

Rivas, C. (2012). Coding and analysing qualitative data. In C. Searle (Ed.), Researching society and culture. London: SAGE Publications.

Robson, C. (2011). Real world research. Hoboken: John Wiley \& Sons.

Shang, J. G., \& Kou, J. N. (2015). The reciprocal effect of learners' individual factors on learner autonomy. Foreign Languages and Their Teaching, (4), 63-67.
Swatevacharkul, R. (2008). An investigation on readiness for learner autonomy, approaches to learning of tertiary students and the roles of English language teachers in enhancing learner autonomy in higher education. Retrieved from http://libdoc.dpu.ac.th/research/134463.pdf

Tesch, R. (2013). Qualitative research: Analysis types and software. Routledge.

Thanasoulas, D. (2002). Motivation and Motivating in the Foreign Language Classroom. TESL Journal, 8(11).

Thavenius, C. (1999). Teacher autonomy for learner autonomy. In S. Cotterall \& D. Crabbe (Eds.), Learner autonomy in language learning: Defining the field and effecting change (pp. 159-163). Frankfurt am Main: Peter Lang.

Wolcott, H. F. (2008). Ethnography: A way of seeing. Maryland: Altamira Press.

Yuliani, Y., \& Lengkanawati, N. S. (2017). Project-based learning in promoting learner autonomy in an EFL classroom. Indonesian Journal of Applied Linguistics, 7(2), 285-293.

Zimmerman, B. J., S. Bonner and R. Kovach (1996). Developing Self-Regulated Learners: Beyond Achievement to Self-Efficacy. Washington, DC: American Psychological Association.

Zhao, Y. (2009). Catching Up or Leading the Way. Alexandria, VA: ASCD.

Conflict of Interest Statement: The authors declare that the research was conducted in the absence of any commercial or financial relationships that could be construed as a potential conflict of interest.

Copyright (C) 2021 Langgeng Budianto and Andrea R. Mason. This is an openaccess article distributed under the terms of the Creative Commons Attribution License (CC BY). The use, distribution or reproduction in other forums is permitted, provided the original author(s) and the copyright owner(s) are credited and that the original publication in this journal is cited, in accordance with accepted academic prac- tice. No use, distribution or reproduction is permitted which does not comply with these terms. 